\title{
EDUCATING THE YOUTH FOR THE IDENTITY OF THEIR RESIDENTIAL REGIONAL SPACE. CASE STUDY: THE LAND OF FĂGĂRAŞ
}

\author{
PAULA OLIVIA CIMPOIEŞ \\ Babeş-Bolyai University, Romania, Faculty of Geography, e-mail: paula.cimpoies@yahoo.com
}

(Received: June 2011; in revised form: August 2012)

\begin{abstract}
This paper aims at contributing to a better understanding of the teaching methods used in school for developing students' civic attitude so that they can become one of the most reliable "resources" in the process of local and regional development. Our research is based on a pilot study which we conducted in order to study regional identity, attitudes and symbols of inhabitants' collective memory in the Land of Făgăraş, in July-August 2012. The results indicate that out of the total number of subjects questioned, 20\% are young people aged 11-21, out of which $99 \%$ are aware of the regional identity of the space they live in. This high value proves that the young generation is responsive to information communicated in teaching environments which they perceive in a different manner, a good basis for cultivating the necessary skills in order to improve living standards for their region. Finally, we planned a teaching unit that could be performed with students aged 1419 (corresponding to the high school period, especially to the $9^{\text {th }}$ and $10^{\text {th }}$ grades) and that integrates activities within one class).
\end{abstract}

Keywords: civic attitude, regional identity, perception of space, regional development, Geography class

\section{INTRODUCTION}

This study aims to highlight the significance of school, particularly of Geography classes, in developing a healthy civic attitude of the young generation representing the future, so that it actively participates to the local and regional development process. The author wrote this paper starting from the idea that inhabitants are the most important "stakeholders" of territorial development, particularly the young generation who undergoes an education process and who can contribute considerably to the revival of the social and economic life. 
The significance of studying the local and regional horizon is a necessity in schools, because, in our opinion, this is the territorial reality to which the individual relates to in the first place, the space where he or she is educated, from a material, spiritual and behavioural point of view.

The current research includes five parts. The first two parts define the theoretical concepts and notions that represent the foundation of our paper, while the third and fourth part describe the investigation method, the pilot study which sets the basis for this scientific approach and its results. The fifth part of the paper presents more details about the case study, in this case an education module designed for children aged 14-19, which might represent a source of inspiration for teachers in the Land of Făgăraş region, but which can also be applied easily in other areas of Romania as it uses general concepts related to the knowledge of the local horizon which represents the individuals' place of origin.

\section{THEORETICAL CONSIDERATIONS}

The characteristic features of the Romanian "lands" consist of the fact that they "cannot be considered geographic regions in the absence of a population who receives and makes use of these characteristics, the data regarding the geographical area is filtered by the fine human psyche" (Ilieş, 1991 , p. 32). In this context, Bold (Bold et. al, 2003) states that the inhabitants of the region represent a factor of economic development only under the circumstances in which they have the possibility to build their awareness regarding their own regional identity.

Before being perceived as fragments of the national mental space, the lands were administrative-territorial entities based on mutual property and exploitation of land. R. Săgeată (2006) asserts that "lands" represent functional spatial entities which need to be legally institutionalized to encourage intercommunal forms of cooperation. The same author explains the fact that the collective mental attitude plays a very important role when building a sustainable partnership between local communities. In other words, the inhabitants' collective memory is one of the many strengths that promote the "lands" as viable development regions, which might work similar to a binder in social, cultural and economic practices.

R. Govers and F. Go. (2009) consider that as local and regional identity is subjected to the process of globalization, it becomes necessary to identify some competitive sustainable benefits in the development process. In the above-mentioned authors' opinion, the relationship between these benefits with "authentic and unique elements such as the regional culture, physical resources, landscapes, historical places and spiritual symbols, which cannot be easily imitated and reproduced in other spaces by another community" is the most efficient manner to perform a local or regional branding strategy (Govers, Go, 2009, p.49).

In line with the previously mentioned concepts (for example, the "regional identity" concept), we asked the following questions: "Can school contribute to the thorough understanding of the social and economic reality 
of the regional environment we live in?" "To what extent is the young generation interested in its own regional identity?" "Which are the means of schools' contribution to the forming of civic attitude towards society?".

Currently, the Romanian Geography curriculum includes several elements related to the understanding of the local horizon. In 2006, the course entitled "An Introduction to Geography. From the Birthplace to Planet Level" was among the matters of study for the fourth grade, but this was only an optional course (Rus, 2010). In addition, the current school curriculum for the $9^{\text {th }}-12^{\text {th }}$ grades mentions the fact that Geography contributes to the shaping of skills useful for the constructive social integration and targets some fields and aspects related to the civic, cultural perspective (School curriculum for the $9^{\text {th }}$ grade, subject: Geography, approved by Order of the Ministry of Education, Research and Youth no. 3458 /09.03.2004).

Therefore, the aim of this research is to highlight the interrelation between the young's education by means of the educational system during Geography classes and the building of a civic attitude directed towards regional and local development.

\section{RESEARCH METHODOLOGY}

The research starts from the results of an investigation conducted in the Land of Făgăraş, in May 2012. The investigation represented the object of study as it revealed the fact that $99 \%$ of students are aware of the regional identity of the area they live in.

The investigation used the non-layered method. Although the group of respondents was initially intended for all age categories (the young, teenagers, adults, and senior) and both life environments (urban, rural), we did not intend to cover a certain percentage for a certain category of respondents.

Generally speaking, the inquiry method translated into practice using the questionnaire as a working tool should satisfy the representativeness requirement as related to an incomparably larger population (Rotariu, Ilut, 2001 , p. 49). Nevertheless, it is possible to use the inquiry on smaller groups of respondents, if special analyses are intended (Rotariu, Ilut, 2001, p. 168).

In building the questionnaire, we aimed at selecting the indicators and at translating them into simple language. The questions included general aspects such as the respondents' origin environment, their level of education, age and some particular aspects, such as their own perception on the "Land of Făgăraş" region boundaries, the symbols associated to the Făgăraş town, the inhabitants' in the region view upon life. The questionnaire was applied to a group of 155 respondents, aged between 11 and 80 . The face-to-face administration of the questionnaire was preferred, but the self-administered questionnaire was also considered, as a result of the cooperation with the teaching staff of the "Doamna Stanca" National High School in Făgăraş town. 


\section{RESULTS}

Of the total interviewed persons (155), 20\% come under the 11-21 age category. Approximately half (45\%) of these $20 \%$ are students, respectively students included in the high school and elementary educational cycle, aged 11-18. Of the total number of pupils subjected to the questionnaire, most of them did not change their place of residence until the date of the survey. However, the few exceptions, those who spent their childhood in other towns, originate also from within the boundaries of the study area (the Land of Făgăraş). Related to the present residential environment, $99 \%$ of the students live in the rural area, while only one student lives in Făgăraş town. In terms of gender, $71 \%$ of the respondents were females and $29 \%$ were males.

Of the most relevant and useful indicators included in the study, one mentions the manner the respondents relate to the Land of Făgăraş living area, the degree of familiarity related to the above-mentioned expression, their capacity to identify key symbols referring to Făgăraş town and to the Land of Făgăraş.

To the first question "Have you heard about the Land of Făgăraş?", $99 \%$ of the questioned pupils replied affirmatively. For the second question, "Do you consider yourself a resident of the Land of Făgăraş?", out of all the responses, $16 \%$ were negative, while $83 \%$ were positive. After data analysis, the nature of the responses resulted to be independent of the respondents' provenance or childhood environment; however, there is no age-related preference for a certain type of answer. We conclude from this that their motivation in assigning the responses is influenced by external environments, respectively by the family environment (what they have learned at home about the region called the Land of Făgăraş) and by the school environment (what they have learned at school about the region called the Land of Făgăraş). This hypothesis is supported also by the indicator addressing the manner of perceiving Făgăraş in the collective memory. Most of the students relate the town to the idea of "history", "beauty", "industry" on one hand, while, on the other hand, others are convinced of the moral and economic decline of the town by associating it with "foulness" and by including such characteristics as "former economic centre", "lack of transport infrastructure".

Conclusively, the young generation is aware of the regional identity of the analyzed area, and $83 \%$ assume it as being part of their living environment. Nevertheless, the building of a regional consciousness does not start very early. According to Kideckel, the building of a regional consciousness of the "Făgărăş" inhabitants is noticed with the Romanian people around the age of 65 (Kideckel, 2006). In this context, school may speed up the process and contribute to the development of people's civic attitude directed towards the local and regional horizon of the young generation.

While the results of the above-presented pilot study have offered us a working hypothesis, in order to draw up the educational module to be used during the Geography classes in the high schools associated to the Land of Făgăraş region, we used the example of a study module performed by 15 teachers in the countries composing the SaarLorLux transboundary region, 
gathered in a project financed by the INTERREG IIIC programme. The educational module was widely presented by Scholz Gundula (2011) in the paper "Der SaarLorLux Raum - zwischen Realität, Illusion und Vision. Wahrnehmung und aktionsräumliches Verhalten aus der Sicht von Bewohnern einer europäischen Grenzregion" and has contributed to the development of awareness regarding the life style in the respective transboundary region.

The project developed during several weekly meetings between teachers and students from the four sub-areas of the SaarLorLux region. Based on five chosen topics, work groups were created to adopt the "puzzle model". This model implies that pupils are involved in a project-based learning situation by the expert panels method, which involves experience exchange after thoroughly studying a certain topic. Before thoroughly studying the topics, students are faced with the situation of becoming familiar with the region, using concepts and approaches from their daily life.

In addition, another model we used was represented by the materials used by the Robert Schuman European Centre, addressing the development of educational methods dedicated partially to the SaarLorLux region, whose objective is to educate European citizens for the European Union area.

Therefore, we decided to adapt the observed strategies, respectively in the first stage the acquaintance with the Land of Făgăraş region during the Geography classes in the $9^{\text {th }}-10^{\text {th }}$ grades.

\section{CASE STUDY- THE LAND OF FĂGĂRAŞ}

In this paper we proposed to design a teaching unit which could be applied within Geography classes, having as a case study the region called the Land of Făgăraş. The unit addresses to high school students, especially in the $9^{\text {th }}$ and in the $10^{\text {th }}$ grades. We took into account students aged 14-19 due to the fact that people from this age and younger (11-12 years old) have the capacity for reflecting on concepts, thinking in an abstract mode, proposing and delivering theories (Piaget, 1969). Knowing the students' cognitive skills is of major importance if we wish to communicate information such as abstract notions, symbols, mental spaces, "land" type entities, which they could reason with, internalize them in their inner set of values and maybe apply them in their daily lives. Thus, students would be able to develop a sense of responsibility for the culture of the region they live in, actively participate in taking decisions; in other words, they would be able to become "stakeholders" in territorial development.

The teaching unit will link students' civic attitude to the spiritual and cultural heritage of the region. Students will become familiar with economic practices as well; in doing so, they will learn about the surrounding reality where they could play the role of engaged citizens.

We included methods and techniques in two parts, as follows: 


\section{Part one - introduction}

In this stage, the teacher presents the objectives of the lesson and displays information in the form of images, drawings, music photographs (Table 1).

Table 1. Activities integrated in the teaching unit (adapted by author after Scholz, 2011)

\begin{tabular}{|c|c|c|c|c|}
\hline $\begin{array}{l}\text { Time spent } \\
\text { per activity }\end{array}$ & Role & Teaching steps & $\begin{array}{l}\text { Procedural } \\
\text { resources }\end{array}$ & Material resources \\
\hline 10 minutes & Introduction & $\begin{array}{l}\text { "Mute" map* of } \\
\text { the Land of } \\
\text { Făgăraş - } \\
\text { administrative } \\
\text { boundaries } \\
\text { (county } \\
\text { boundaries) - } \\
\text { main cities }\end{array}$ & $\begin{array}{l}\text { Heuristic } \\
\text { dialog } \\
\text { Analysis of } \\
\text { the "mute" } \\
\text { map }\end{array}$ & $\begin{array}{l}\text { Overhead } \\
\text { projector }\end{array}$ \\
\hline 8 minutes & $\begin{array}{l}\text { Development } \\
\text { of the topic }\end{array}$ & $\begin{array}{l}\text { - which are the } \\
\text { elements of the } \\
\text { physical } \\
\text { environment } \\
\text { characteristic } \\
\text { of the Land of } \\
\text { Făgăraş? }\end{array}$ & $\begin{array}{l}\text { Heuristic } \\
\text { dialog }\end{array}$ & $\begin{array}{l}\text { Physical map of } \\
\text { the region } \\
\text { Overhead } \\
\text { projector }\end{array}$ \\
\hline 5 minutes & $\begin{array}{l}\text { Strengthening } \\
\text { knowledge }\end{array}$ & $\begin{array}{l}\text { Transfer of } \\
\text { elements from } \\
\text { the blackboard } \\
\text { on the working } \\
\text { sheets }\end{array}$ & $\begin{array}{l}\text { Individual } \\
\text { work }\end{array}$ & Working sheets \\
\hline 10 minutes & $\begin{array}{l}\text { Development } \\
\text { of the topic }\end{array}$ & $\begin{array}{l}\text { How do you } \\
\text { see your daily } \\
\text { life in the } \\
\text { region? } \\
\text { Do } \\
\text { consider you } \\
\text { yourself an } \\
\text { inhabitant of } \\
\text { the Land of } \\
\text { Făgăraş? }\end{array}$ & Team work & Working sheets \\
\hline 7 minutes & $\begin{array}{l}\text { Extensive } \\
\text { knowledge }\end{array}$ & $\begin{array}{l}\text { Music/folk } \\
\text { costumes } \\
\text { represent the } \\
\text { area }\end{array}$ & $\begin{array}{l}\text { Heuristic } \\
\text { dialog }\end{array}$ & $\begin{array}{l}\text { CD player } \\
\text { Overhead } \\
\text { projector }\end{array}$ \\
\hline 10 minutes & \multicolumn{2}{|l|}{ Conclusions } & $\begin{array}{l}\text { Heuristic } \\
\text { dialogue }\end{array}$ & Blackboard \\
\hline 10 minutes & \multicolumn{2}{|c|}{$\begin{array}{ll}\text { Informing about } & \text { the } \\
\text { forthcoming activities }\end{array}$} & Monologue & Working sheets \\
\hline
\end{tabular}


Examples of activities that could be integrated in the first phase:

Strategy 1 . Starts with a brainstorming session. What are the first features that come to your mind when you think about the Land of Făgăraş? Write keywords on the sheets or draw a symbol which you consider as representative!

The "mute" map is presented (Figure 1). Based on this map, students have the following tasks:

a) Localize on the map the locality you live in! Is this located in the Land of Făgăraş? Why did you consider that it is a part/it is not a part of the Land of Făgăraş?

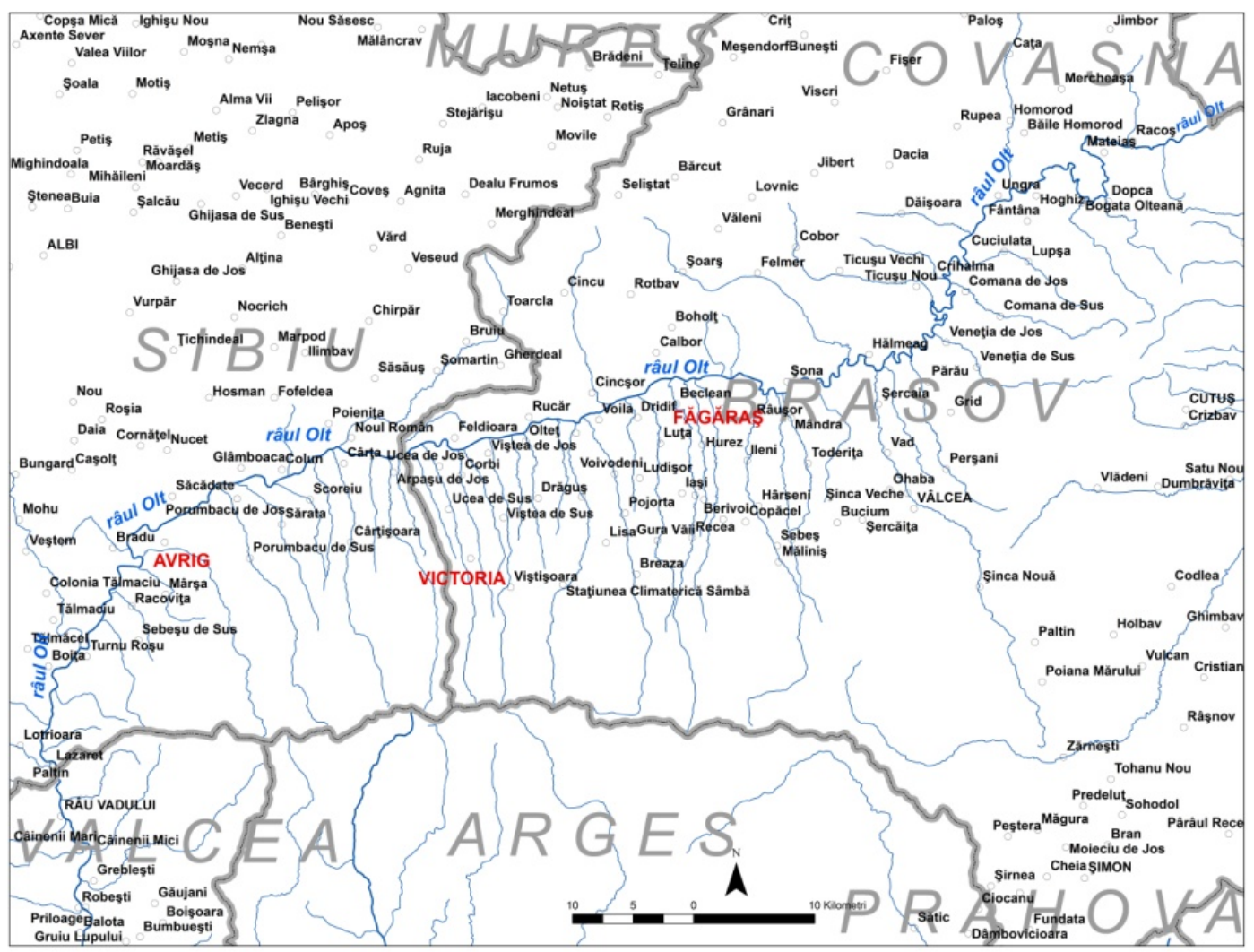

Fig. 1. The Land of Făgăraş - extra-regional context

b) You noticed that the Land of Făgăraş extends on two neighbouring counties. Which are these counties?

c) Analyze the map and indicate the main river streams and the cities in this region.

d) The CD with folkloric music plays. At the same time, the teacher displays photographs with folkloric costumes. For this task, students will form groups of three. The task is to make connections between different costumes and the subarea they are characteristic of. Work in groups, analyze the photographs and attach on the map the photographs that correspond to each subarea (Avrig, Făgăraş, Perşani). 
e) Individual task. After getting acquainted with the map, students will have to draw on their sheets (A4 copies of the "mute" map) the way in which they see the boundaries of the Land of Făgăraş. The teacher will act as a moderator of the debate about students' manifold perceptions on the limits of the region. State the reason why you chose to add in the drawn limit certain localities, rivers, relief forms!

\section{Part two - perception of space}

According to the tasks chosen in part one and the time spent per activity, the teacher decides if he or she continues with part two in the same teaching class or leaves it for the next one. We need to keep in mind that this task enables students to remember their personal experience related to the region and discuss it with their colleagues.

\section{How do you see your daily life in the region you live in?}

Working task: Analyze the following table. What are the reasons for travelling to these localities? Tick the boxes that correspond with your motivation or complete the empty spaces. Give arguments for your choices!

Working time: 15 minutes

Working mode: individual

\begin{tabular}{|c|c|c|c|c|c|c|c|}
\hline $\begin{array}{l}\text { Locality/ } \\
\text { reason for } \\
\text { travelling }\end{array}$ & Făgăraş & Braşov & Rupea & Avrig & Victoria & Sibiu & $\begin{array}{c}\text { Other } \\
\text { localities }\end{array}$ \\
\hline I live here & & & & & & & \\
\hline Shopping & & & & & & & \\
\hline $\begin{array}{c}\text { Work } \\
\text { School }\end{array}$ & & & & & & & \\
\hline $\begin{array}{c}\text { Excursions } \\
\text { Sports }\end{array}$ & & & & & & & \\
\hline $\begin{array}{l}\text { Theatre } \\
\text { Cinema } \\
\text { Concerts } \\
\text { Night life }\end{array}$ & & & & & & & \\
\hline $\begin{array}{l}\text { Visiting } \\
\text { relatives and } \\
\text { friends }\end{array}$ & & & & & & & \\
\hline
\end{tabular}

Fig. 2. Working sheet for part two

The teacher distributes working sheets as questionnaires (Figure 2) to each student. While using this methods it is desirable that students reflect upon space, refer to it in peculiar aspects (as a resident, as a commuter, as a tourist). 
The questionnaire can be easily used as a teaching method due to the fact that it urges to enquire and reflect in order to find answers to be used in group work or in plenary debates.

Examples of activities that can be integrated in part two:

a) Take a look at the localities listed on the working sheet. Specify which localities you consider most attractive! (1=most attractive, 10=least attractive). Why do you consider one particular locality to be less or more attractive?

b) Carefully consider the town of Făgăraş. What strengths or weaknesses does this town have?

These tasks are intended to activate students' emotional level. Therefore, they will be motivated to investigate further about the Land of Făgăraş, outside classes.

\section{CONCLUSION}

The teaching unit drawn up in this paper represents an introduction into the insights of the region called the Land of Făgăraş. Furthermore, shaping a civic attitude for the inhabitants in this region could be achieved by integrating activities which involve learning practical skills. These practical skills implemented as role games or groups of experts are accessible for high school students in the $11^{\text {th }}$ and $12^{\text {th }}$ grades.

In conclusion, the role of the school in raising awareness of the identity of regional spaces (e.g. the "lands" in Romania), is fundamental for their socio-economic development. The education system, particularly Geography classes, have the ability to form students according to new trends in the planning process.

\section{References}

Bold, I. et. al. (2003). Spaţiul rural. Definire, Organizare, Dezvoltare. Timişoara: Editura Mirton.

Govers, R., \& Go, F. (2009). Place Branding. Glocal, Virtual and Physical Identities, Constructed, Imagined and Experienced. Basingstoke: Palgrave Macmillan.

Ilieş, G. (1991). Tipuri de conotaţii ale termenului de "țară". Revista Română de Geografie Politică, 1(1), 31-35.

Kideckel, D. (2006). Colectivism şi singurătate în satele româneşti. Țara Oltului în perioada comunistă şi în primii ani după revoluţie. Iaşi: Polirom.

Piaget, J. (1969). The mechanisms of Perception. London: Routledge\&Kegan Paul.

Programa şcolară pentru clasa a IX, disciplina geografie, aprobată prin Ordin al Ministrului Educaţiei, Cercetării şi Tineretului nr. 3458 / 09.03.2004, Retrieved 10 June 2012, from http://www.edu.ro/index.php/articles/6238. 


\section{PAULA OLIVIA CIMPOIEŞ}

Rotariu, T., \& Iluţ, P. (2001). Ancheta sociologică şi sondajul de opinie: teorie şi practică. Iaşi: Polirom.

Rus, D. (2010). Necesitatea reintroducerii studiului geografiei judeţului în programele şcolare. In E.M. Dulamă, F. Bucilă, O.R. Ilovan (Eds.), Tendinţe actuale în predarea şi învăţarea geografiei/Contemporary Trends in Teaching and Learning Geography. Cluj-Napoca: Presa Universitară Clujeană.

Săgeată, R. (2007). The "Pays" - Inter-Communal Cooperation and Territorial Planning Units. The French Experience and its Applicability to Romania. In V. Surdd, V. Zotic (Eds.), Rural Space and Local Development. Cluj-Napoca.

Scholz, Gundula, (2011). Der SaarLorLux Raum- zwischen Realität, Illusion und Vision. Wahrnehmung und aktionsräumliches Verhalten aus der Sicht von Bewohnern einer europäischen Grenzregion. Institut für Landeskunde im Saarland e. V., Saabrücken. 